showing cerebral oedema with diffuse haemorrhagic necrosis microscopically and widespread mononuclear cell infiltration of perivascular distribution. The encephalopathy in our case 2 was less severe and not the cause of death, which explains the lack of a characteristic histology.

Abnormal liver function values are found in $93 \%$ of cases of infectious mononucleosis, with a raised serum bilirubin in $40 \%$ and visible jaundice in $17 \%$. The changes are attributed to hepatocellular damage, and in 19 out of 22 cases examined histologically the liver was abnormal ${ }^{4}$, usually with mononuclear cell infiltration of portal and sinusoidal areas and scattered focal necrosis, the features seen in case 1 . Only two cases of fatal hepatic necrosis convincingly associated with infectious mononucleosis have been described. ${ }^{2}$ Liver histology was similar to that in our case 2 , with hepatic necrosis predominantly centrilobular in distribution and mononuclear cell infiltration of portal tracts.

Thrombocytopenia, haemolytic anaemia, ${ }^{5}$ and absolute neutropenia are common incidental findings in infectious mononucleosis but there are eight case reports of extreme neutropenia with recovery in the recent English literature. Only one previous death from infectious mononucleosis complicated by hypoplastic anaemia, agranulocytosis, and septicaemia has been reported. ${ }^{5}$

We are most grateful to Dr. J. D. Crosswell for referring the cases, and to Dr. Joan Edwards, of the Virus Reference Laboratory, Colindale, for her help and advice.

${ }^{1}$ Bernstein, T. C., and Wolff, H. G., Annals of Internal Medicine, 1950, 33, 1120.

2 Penman, H. G., fournal of Clinical Pathology, 1970, 23, 765

3 Di Benedetto, R. J., and Jurgensen, P. F., Southern Medical fournal, 1974, 67, 736.

4 Nelson, R. S., and Darragh, J. H., American fournal of Medicine, 1956, 21, 26.

5 Worlledge, S. M., and Dacie, J. V., in Infectious Mononucleosis, ed. R. L. Carter, and H. G. Penman. Oxford, Blackwell Scientific, 1969.

Royal Free Hospital, London NW3 2QG

STEPHAN JAIN, M.B., M.R.C.P., Honorary Lecturer in Medicine SHEILA SHERLOCK, M.D., F.R.C.P., Professor of Medicine

\section{Arsenical Polyneuropathy due to Caustic Arsenical Paste}

Early this century arsenical polyneuritis was common and usually caused by ingesting foods containing arsenic. ${ }^{1}$ The condition is less common now and mainly caused by ingesting or inhaling agricultural pesticides. ${ }^{2}$ In the following case arsenical polyneuritis was due to the application of a caustic arsenical paste as a quack cancer remedy.

\section{Case Report}

A 59-year-old man who lived in isolated countryside developed a small lesion on his right cheek which his general practitioner found indistinguishable from a carcinoma. The patient refused to attend hospital, but when the lesion got bigger he consulted a "cancer curer," who applied treatment locally. This treatment seemed to be a paste, though the patient refused to disclose any details. A large sloughing area appeared on the right cheek. On admission four weeks after "treatment" he could not walk or stand, though he had been an active man despite severe kyphosis and chronic bronchitis. On examination he was ill-nourished, slightly anaemic, and dehydrated and had pitting oedema of the ankles and a pyrexia of $37.8^{\circ} \mathrm{C}$. There was a large infected ulcer on the right cheek (see fig.), and the buccal mucosa was inflamed and coated with an infected slough.

There was no jaundice, cyanosis, finger clubbing, obvious generalized skin lesion, or hepatosplenomegaly. There was definite peripheral weakness, and he could just flex and extend the knees against slight pressure, but there was no movement in the ankle joints, and the hands were weak. The upper limb reflexes were present but not knee and ankle jerks, and the plantar responses were equivocal. There was obvious sensory loss in the hands and legs, and the patient complained of a burning sensation in the hands and feet. As he was depressed, withdrawn, and of limited intelligence it was difficult to know if there was any personality change.

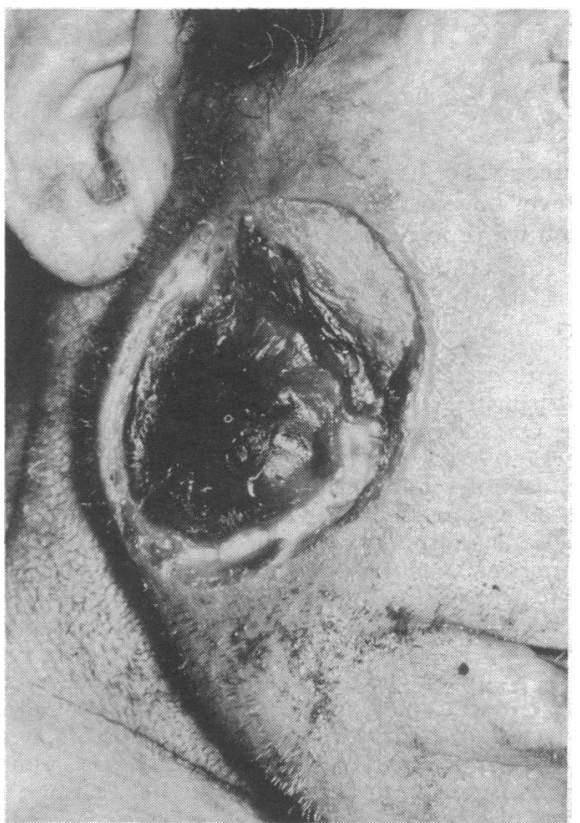

Infected ulcer caused by application of caustic arsenical paste.

Investigations.-Haemoglobin was $9.9 \mathrm{~g} / \mathrm{dl}$; red cell count $3.8 \times 10^{12} / 1$; packed cell volume $33 \%$; mean cell volume $87 \mathrm{fl}$; and white cell count $2 \cdot 1 \times$ $10^{9} / 1$ with polymorphs $30 \%$, lymphocytes $41 \%$, monocytes $4 \%$, eosinophils $33 \%$, and mononuclear cells $2 \%$. The erythrocyte sedimentation rate was $70 \mathrm{~mm}$ in one hour (Westergren); electrolytes were normal, and blood urea was $15.3 \mathrm{mmol} / 1$ (92 $\mathrm{mg} / 100 \mathrm{ml})$. Electrocardiography showed a sinus tachycardia with right ventricular preponderance. Cerebrospinal fluid pressure was normal; white cells were $5 \times 10^{6} / 1$, protein $300 \mathrm{mg} / \mathrm{l}$, and globulins absent. Blood sugar was $3.6 \mathrm{mmol} / 1(65 \mathrm{mg} / 100 \mathrm{ml})$ and serum lead $0.87 \mu \mathrm{mol} / 1(18 \mu \mathrm{g} / 100 \mathrm{ml})$ (normal 0.34-1.9 $\mu \mathrm{mol} / 1(7-40 \mu \mathrm{g} / 100 \mathrm{ml})$ ). In three 24-hour urine specimens arsenic levels were $800.8,1868.5$, and $5338.8 \mathrm{nmol} / 1(6,14$, and $80 \mu \mathrm{g} / 100 \mathrm{ml}$ ) (normal $133.47 \mathrm{nmol} / 1$ (1 $\mu \mathrm{g} /$ $100 \mathrm{ml})$ ). Arsenical peripheral polyneuropathy complicated by severe bronchitis and emphysema was diagnosed.

Treatment.-Antibiotics were given for the chest infection and dimercaprol for arsenic poisoning. The patient developed a severe generalized reaction. His temperature rose to $39.4^{\circ} \mathrm{C}$, and his general condition deteriorated, so dimercaprol was stopped and he needed plasma expanders and hydrocortisone because of hypotension. Sodium calcium edetate was started. The slough on his face became larger and was removed; histologically it showed "non-specific necrosis with no evidence of carcinoma." Despite supportive treatment, antibiotics, and physiotherapy his chest condition and peripheral neuropathy became worse, and he developed generalized skin lesions, the skin breaking easily and the nails thickening. Despite blood transfusions he became progressively anaemic and died one month after admission.

\section{Discussion}

Caustic pastes were used to treat cancer until early this century and they survive as quack cancer remedies, ${ }^{3}$ especially in rural areas, where arsenic, which is considered to be an active agent against cancer, is easily obtained. Most reports of arsenical polyneuropathy emphasize the combination of subjective and objective sensory disturbance with peripheral weakness. ${ }^{24}$ Response to treatment seems to be slow, and the respiratory system is often involved. In this case peripheral neuropathy, acute respiratory involvement, and chronic bronchitis combined proved fatal.

1 Kelynack, T. N., et al., Lancet, 1900, 2, 1600.

2 Heyman, A., et al., New England fournal of Medicine, 1956, 254, 401.

3 Dickie, W. R., and Hughes, N. C., British Fournal of Plastic Surgery, $1961,14,97$

${ }^{4}$ Hassin, G. B., Fournal of Nervous and Mental Disease, 1930, 72, 628.

Banbridge Hospital, Banbridge, Co. Down

T. J. ROBINSON, M.D., M.R.C.P., Consultant Physician

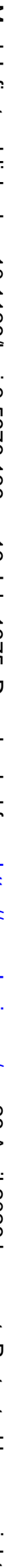

